Original Article

\title{
LYCOPENE PRODUCTION IN MYCOBACTERIUM SMEGMATIS BY EXPRESSION OF CRT GENES FROM MYCOBACTERIUM AURUM AND PROTECTIVE EFFECT OF LYCOPENE IN VIVO AND IN VITRO AGAINST UV RADIATION
}

\author{
OUMAIMA ELAMIN, MARWA CHRAIBI, SAAD KORAICHI IBNSOUDA, MOHAMMED HOUSSAINI IRAQUI
}

Sidi Mohamed Ben Abdelah University, Faculty of Sciences and Technologies, Department of Microbiology, B. P. 2202, Imouzzer Street, Fes, Morocco

Email: oumaima.elamin@usmba.ac.ma

Received: 10 Mar 2018 Revised and Accepted: 30 Jul 2018

\section{ABSTRACT}

Objective: The aim of the present study was to express in Mycobacterium smegmatis the clustered mycobacterial genes coding for lycopene synthesis and to investigate the protective properties of lycopene against ultraviolet (UV) irradiation.

Methods: The genes, which encode the biogenesis of lycopene in Mycobacterium aurum A+, were introduced into Mycobacterium smegmatis by electroporation. The pigments produced were analyzed by thin layer chromatography, and the absorption spectra were determined. A survival test using UV irradiations was also performed.

Results: The transformed Mycobacterium smegmatis were found to synthesize lycopene with important yield (1.41 \pm 3.09 mg/g) and was more resistant to ultraviolet irradiation than non-pigmented strain $(\mathrm{p}<0.01)$. Furthermore, cells of M. smegmatis not transformed but coated with lycopene are more resistant to UV than those uncoated $(\mathrm{p}<0.01)$.

Conclusion: M. smegmatis can form orange colonies on agar plates when it is transformed with the lycopene genes, and the transformants produces $1.41 \mathrm{mg} / \mathrm{g}$ (dry weight) of this carotene. Our findings strongly suggest that lycopene has antioxidant activities and prevent the lethal action of UV irradiation on bacterial cells in vivo and in vitro, and deserves further studies considering the amelioration of the production.

Keywords: Mycobacterium smegmatis, Lycopene, Plasmid, UV irradiation

(c) 2018 The Authors. Published by Innovare Academic Sciences Pvt Ltd. This is an open-access article under the CC BY license (http://creativecommons.org/licenses/by/4.0/) DOI: http://dx.doi.org/10.22159/ijpps.2018v10i9.25768

\section{INTRODUCTION}

Carotenoids are a big family of fat-soluble pigments largely distributed in nature, in anoxygenic and oxygenic photosynthetic bacteria, algae and in many fungi, but animals and human are not able to produce this kind of pigments themselves $[1,2]$. Carotenoids are a class of hydrocarbon compounds that can be chemically subdivided into xanthophylls (oxygenated molecules) and carotenes (hydrocarbons lacking oxygen). These tetraterpenes usually consist of 8 isoprene units derived from isopentenyl diphosphate [3].

Carotenoids are produced through two different stages, the early steps and the later steps. The early steps include the formation of geranylgeranyl pyrophosphate (GGPP) from farnesyl pyrophosphate (FPP) by GGPP synthase (an enzyme encoded by the $\operatorname{crtE}$ gene). The formation of phytoene from GGPP is catalyzed by phytoene synthase (an enzyme encoded by the $\operatorname{crtB}$ gene). The phytoene obtained is then dehydrated by a phytoene dehydrogenase (an enzyme encoded by the crtI gene) by converting phytoene into lycopene via the following intermediate molecules: phytofluene, zeta-carotene and neurosporene [4-6].

Many carotenoid biosynthesis genes have been cloned and characterized from various organisms, and the functions of the gene products have been demonstrated $[7,8]$.

Lycopene (molecular formula: $\mathrm{C}_{40} \mathrm{H}_{56}$ ), is a bright red phytochemical pigment. It is present with a considerable concentration in tomatoes, some fruits, and vegetables [9]. Lycopene is the most common carotenoid in the human body. It is classed among the most potent antioxidants [10]. It is also, one of the most commercially carotenoids.

A great deal of interest has recently been focused on lycopene due to its excellent performance as an antioxidant [11], anticancer [12], antiinflammatory $[13,14]$, and antimicrobial substance [15]. It has been used as a pharmaceutical compound, nutraceutical, functional food, and cosmetics additive. The global lycopene market was about $1.5 \mathrm{G} \$$ in 2014 and is expected to reach 1.8 G\$ by 2019 [4]. Potential commercial applications mean that efficient biotechnological production of lycopene has become increasingly necessary [16]. Industrial lycopene production is mainly assured by chemical synthesis and extraction from tomatoes [17], although some lycopeneproducing microorganisms are also being used on a smaller scale [18].

The aim of the present study was to evaluate the radioprotective effect of lycopene on UV radiation-induced cellular damage. Thus, we decided to express in Mycobacterium smegmatis the carotenogenesis genes from Mycobacterium aurum $\mathrm{A}^{+}$.

\section{MATERIALS AND METHODS}

\section{Chemicals}

The following Solvents are used in pigments analysis and chemical tests: methanol (LabKem, Spain), chloroform (Sigma-ALDRICH, Germany), acetone (Sigma-ALDRICH, France) and petroleum ether (Sigma-ALDRICH, Germany). All other ingredients used were of analytical grades.

Bacterial strains, plasmids, media and growth conditions

M. smegmatis MC2-155 ( $\mathrm{kan}^{\mathrm{s}}$ [19], laboratory stock) was used in the current study. Growth conditions were chosen according to the experimental requirements. Mycobacterial strains were grown at $37^{\circ} \mathrm{C}$, in sauton medium (monopotassium phosphate, $1.0 \mathrm{~g} / \mathrm{l}$; disodium phosphate, $2.5 \mathrm{~g} / \mathrm{l}$; magnesium sulfate, $0.01 \mathrm{~g} / \mathrm{l}$; zinc sulfate, 0.001 $\mathrm{g} / \mathrm{l}$; copper sulfate, $0.001 \mathrm{~g} / \mathrm{l}$; ferric ammonium citrate, $0.05 \mathrm{~g} / \mathrm{l}$; Casitone $2.0 \mathrm{~g} / \mathrm{l}$; asparagine, $5.0 \mathrm{~g} / \mathrm{l}$; and glycerol, $10.0 \mathrm{~g} / \mathrm{l})$ [20, 21].

M. smegmatis MC2-155 strain was used as a host for the plasmids (pC51 and pHLD69). The pC51 plasmid consists of pHLD69 vector and an insert of approximately $4.42 \mathrm{~kb}$ containing the $M$. aurum crtE, $\operatorname{crtB}$ and $\operatorname{crtI}$ genes necessary for lycopene biosynthesis [22]. The 
pHLD69 vector contains pUC19, the Ori R of pAL5000, and the Kan gene. The Ori $\mathrm{R}$ is responsible for plasmid replication in mycobacteria [23].

When necessary, media were supplemented with kanamycin (Kan) at a concentration of $50 \mu \mathrm{g} / \mathrm{ml}$.

\section{Transformation of $M$. smegmatis by electroporation}

Cells were transformed with pC51 plasmid. The transformants obtained were then selected on a sauton medium containing an appropriate concentration of Kan. The preparation of $M$. smegmatis competent cells and the electroporation were performed by using procedures identical to those described by Snapper et al. [19]. DNA was introduced into mycobacterial cells using the Gene Pulser (Biorad) set at $2.5 \mathrm{kV}, 25 \mu \mathrm{F}$, with the pulse controller resistance set at $200 \Omega$. Approximately $2 \mu \mathrm{g}$ of plasmid DNA was transferred to a pre-cooled $1 \mathrm{~mm}$ electroporation cuvette containing electrocompetent cells. The cuvettes were placed in the electroporator and subjected to a single pulse. The cells were immediately transferred to 1 $\mathrm{ml}$ sauton medium and incubated at $37{ }^{\circ} \mathrm{C}$ for $3 \mathrm{~h}$. The transformants were then screened and cultured on sauton plates with Kan at 50 $\mu \mathrm{g} / \mathrm{ml}$ and $37^{\circ} \mathrm{C}$.

\section{Extraction and purification of carotenes}

Chloroform/methanol (1: $1, \mathrm{v} / \mathrm{v}$ ) were used to extract carotenoid pigments from the transformants carrying the lycopene biosynthesis gene cluster until all visible pigments were removed. After the centrifugation step ( $4000 \mathrm{rpm}$ for $5 \mathrm{~min}$ ), the supernatants obtained were pooled and dried under vacuum. The colored residues were then dissolved in pure acetone, refrigerated at 4?C for two hours, and then clarified by centrifugation. The extracts were dried and dissolved in methanol: petroleum ether $(1: 1, \mathrm{v} / \mathrm{v})$. The mixtures were vigorously vortexed, and the pigments were then allowed to partition. The upper phase was collected, evaporated to dryness and the residue obtained was dissolved in acetone for chromatographic analysis [22]. The entire extraction process was performed under low-light conditions to prevent photo bleaching and degradation.

\section{Thin-layer chromatography (TLC)}

The epiphasic pigments were separated by preparative TLC using watman-silica gel $60 \mathrm{~A}$ plates. The latters, were subsequently developed using $2 \%(\mathrm{v} / \mathrm{v})$ acetone in petroleum ether as a running solvent. Lycopene from tomato was extracted in accordance with the method described by Lu et al., 2008 [24] and used as a standard. The individual zone on the chromatogram was separated, eluted with acetone, and then, spectra were measured. Identification of carotenoids was carried out by comparing the individual characteristic absorption spectrum and chromatographic properties with a known standard and published data [22, 23].

\section{Quantification of lycopene levels}

The cells containing pC51 plasmid were grown on sauton agar for seven days. The pigments were extracted as described above. The lycopene content of the extracts was determined by visible light absorption spectra using a spectrophotometer (BK-UV1000;
BIOBASE, China). Finally, spectras were recorded in acetone using an extinction coefficient of 3450 .

\section{Protective effect of lycopene in vivo}

M. smegmatis cells containing the plasmid pC51 and cultivated on sauton-agar at $37{ }^{\circ} \mathrm{C}$ for $7 \mathrm{~d}$ were diluted to have $10^{4} \mathrm{cells} / \mathrm{ml} .100 \mu \mathrm{l}$ of the diluted culture was plated on sauton-agar medium and then irradiated for a given period of time $(4,6,8,10,11$ or $12 \mathrm{~min})$ using a UV lamp (6 W-254 nm tube; Vilber Lourmat, French) from a distance of $57 \mathrm{~cm}$. The number of bacterial colonies was determined after 7days of incubation. The same method was used for the controls (M. smegmatis and M. smegmatis transformed by pHLD69). The average values were calculated based on six replicate measurements.

The statistical student test [25] is used to compare the resistance of strains to UV radiation. Statistical significance was defined as $\mathrm{p}<0.01$.

\section{Protective effect of lycopene in vitro}

This experiment aims to evaluate the capacity of lycopene to protect, in vitro, M. smegmatis cells against UV radiation. Lycopene used in this experiment was extracted from $M$. smegmatis transformed with pC51 according to the protocol described above. The lycopene extracted was solubilized in the sweet al. mond oil so as to have a concentration of $0.1 \mathrm{mg} / \mu \mathrm{l}$ of oil. Liquid culture of $M$. smegmatis was prepared, and the D. 0 was adjusted to $0.1 .900 \mu \mathrm{l}$ of this culture is transferred to each of the following tubes:

- Tube 1: contains lycopene solubilized in $100 \mu \mathrm{l}$ of almond oil. The final concentration of lycopene was $0.01 \mathrm{mg} / \mu \mathrm{l}$ of oil.

- $\quad$ Tube 2: contains $100 \mu \mathrm{l}$ of sweet al. mond oil (control).

- Tube 3: contains $100 \mu \mathrm{l}$ of sauton broth (control).

$100 \mu \mathrm{l}$ of each tube was plated on sauton agar medium and then exposed to UV light using an UV lamp (6 W-254 nm tube; Vilber Lourmat, French) with respect to the distance from UV lamp (57 cm) and the exposure times $(5,10,15$ and $20 \mathrm{~min})$.

\section{Statistical analysis}

The experiments are repeated three times. Results were expressed as mean \pm standard deviation (SD) of the three triplicates. Student's statistical test was used to compare the resistance of different tests to UV radiations.

\section{RESULTS}

\section{Obtaining of orange-pigmented colonies of $M$. smegmatis}

In the present study, M. smegmatis (a bacterium capable of forming non-pigmented colonies) was transformed with the pC51, vector constituted of the pHLD69 plasmid, and an insert of $4.42 \mathrm{~kb}$ containing genes necessary for lycopene biosynthesis [22]. All transformants obtained were orange (fig. 1), whereas M. smegmatis harboring pHLD69 was not pigmented and did not form any carotene. It was therefore concluded that the insert of pC51 is responsible of the pigmentation of this bacteria.

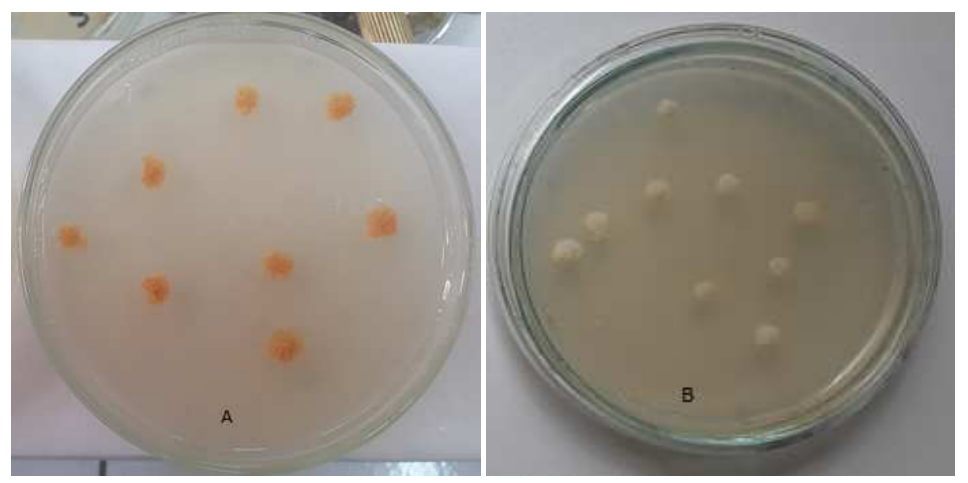

Fig. 1: Colonies of M. smegmatis transformed with pC51 plasmid (A) and M. smegmatis none transformed (B) 


\section{Analysis of carotenoids}

Pigments produced by M. smegmatis harboring pC51 plasmid were extracted, purified and analyzed by TLC (fig. 2). The extracted carotenoid pigments were identified as shown in fig. 2 and fig. 3.

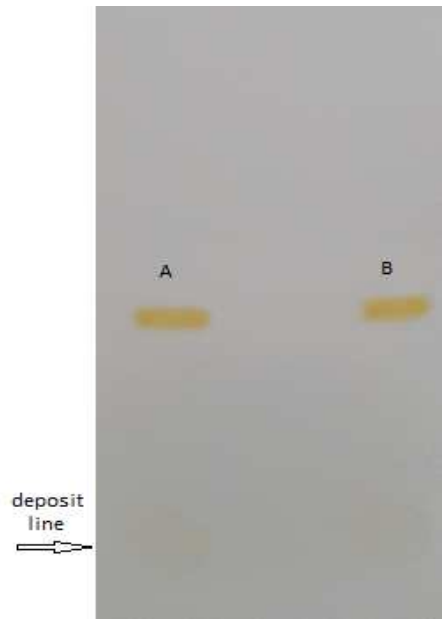

Fig. 2: TLC analysis of lycopene extracted from tomato (A) and pigment produced by $M$. smegmatis transformed with pC51 plasmid (B)

The TLC chromatogram of extracts from $M$. smegmatis transformed with pC51 plasmid shows the presence of one major compound. It also shows that the absorption spectrum of the purified and eluted carotenoid was identical to that of lycopene especially that from tomato (fig. 3). This means that the orange color of the pigmented strain was mainly caused by the accumulation of lycopene. Thus, the results obtained in this section demonstrate that lycopene was formed by the transformants and it was the major end product of carotenogenesis in transformants.

\section{Quantification of lycopene levels}

The lycopene levels were determined using stationary-phase-grown cells by extraction followed by spectral analysis. The M. smegmatis transformed by pC51 yielded value of $1.41 \pm 3.09 \mathrm{mg} / \mathrm{g}$ (dry weight) of lycopene.

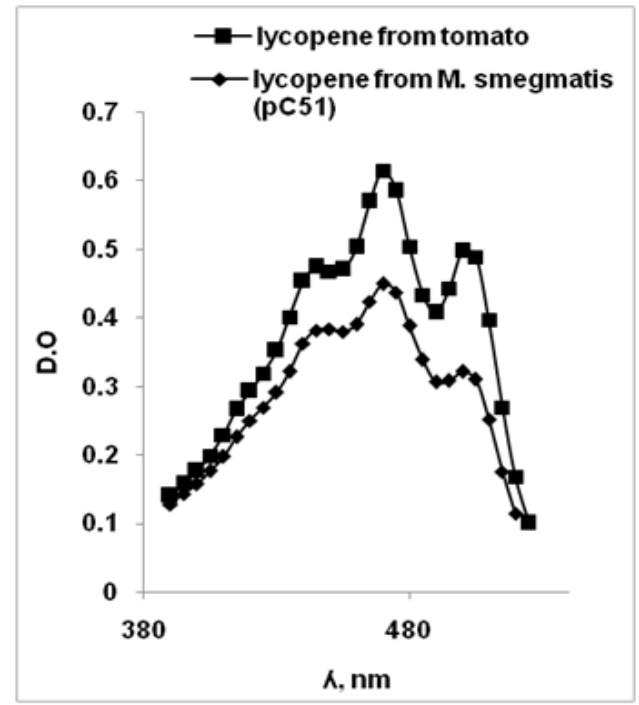

Fig. 3: The spectrum of pigments and lycopene extracted from M. smegmatis (pC51) and tomato, respectively

\section{Lycopene effect in vitro and in vivo on the survival rate of $M$. smegmatis}

To evaluate the in vitro and in vivo antioxidant activity of lycopene produced by $M$. smegmatis transformed by pC51 plasmid, an investigation on survival M. smegmatis strains in the presence of UV light was carried out. The idea was based on the exposition of $M$. smegmatis transformed by pC51 plasmid and M. smegmatis covered by a layer of lycopene to UV light.

The results show that at a distance of $57 \mathrm{~cm}$, cells of $M$. smegmatis transformed by pC51 plasmid were more resistant compared to the parallel controls ( $M$. smegmatis and $M$. smegmatis containing pHLD69) (fig. 4), and M. smegmatis MC2 cells which were coated by lycopene $(0.01 \mathrm{mg} / \mu \mathrm{l})$ were more resistant to UV compared to those uncoated or those coated with oil only (fig. 5). The statistical test also shows that the observed differences in terms of survival fraction were significant. As a conclusion, lycopene can reduce the lethal action of UV radiation significantly, and that could contribute to protect cells in vitro and in vivo from UV light.

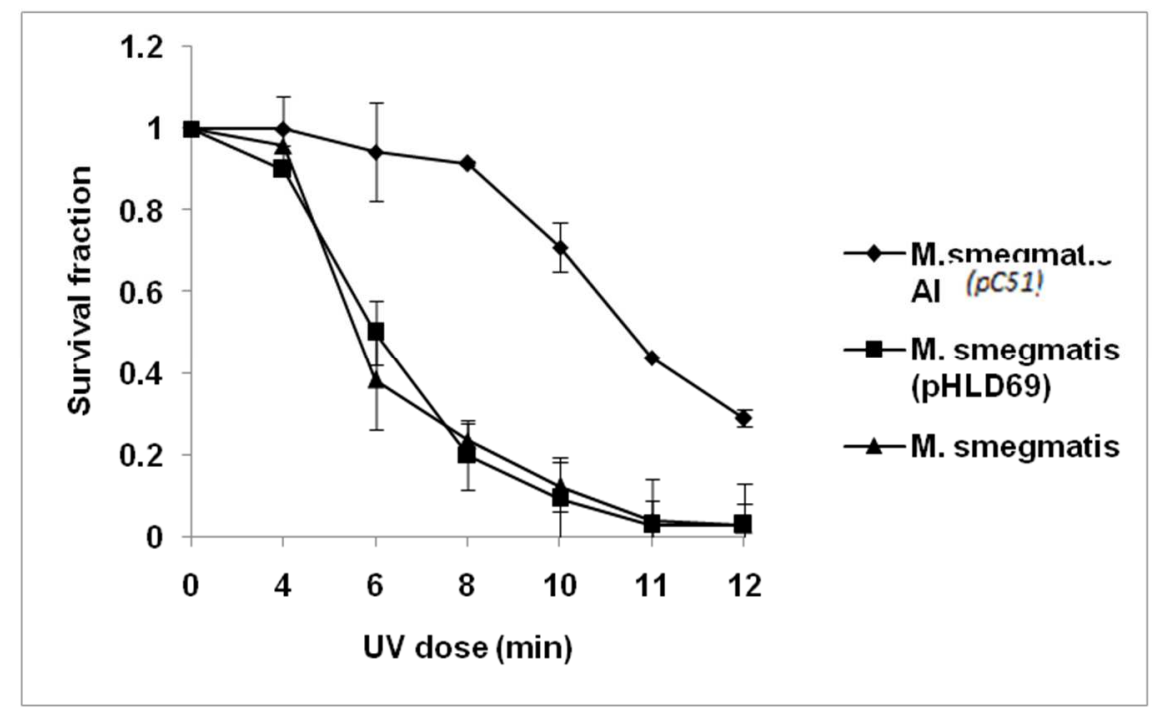

Fig. 4: Susceptibility of various $M$. smegmatis strains to $U V$ radiations, data are shown as mean $\pm S D, n=3, p<0.01$ is considered statistically significant 


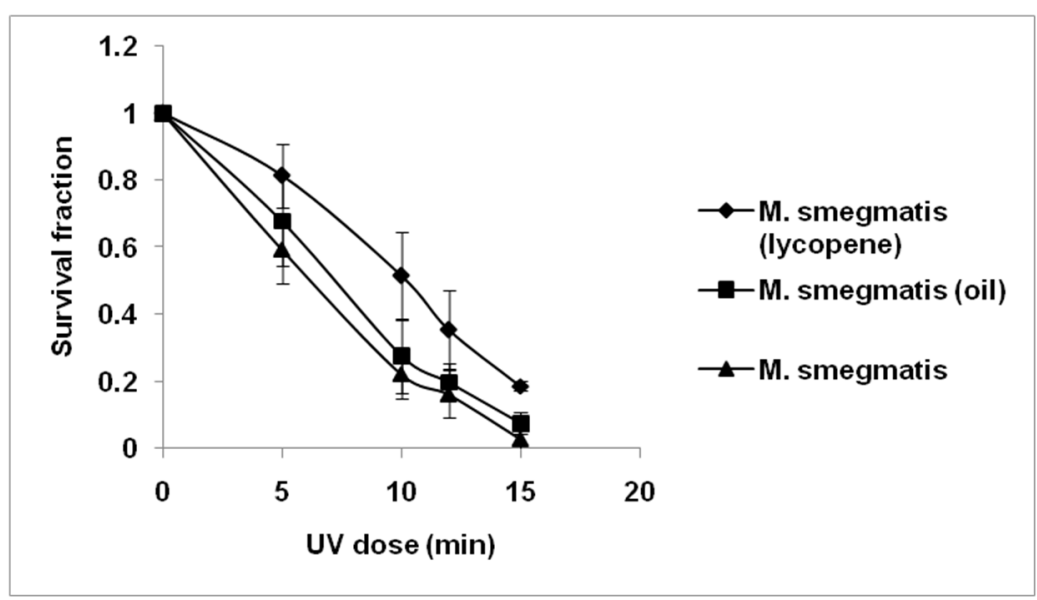

Fig. 5: Protector Effect of lycopene in vitro against $U V$ radiations, values are expressed as mean $\pm S D, n=3, p<0.01$ is considered statistically significant

\section{DISCUSSION}

In many studies, carotenoid synthesis was found to be dependent on the amount and the activity of the carotenoid biosynthetic enzymes. In fact, the application of recombinant DNA technology can be used to increase the carotenoid productivity [26]. This is consistent with the finding published by Iraqui et al. [22] who obtained orange clones of $E$. coli in the presence of pC51.

In the present study, successful production of lycopene in $M$. smegmatis $\mathrm{MC}^{2}-155$ transformed with mycobacterial genes has been demonstrated and validated. The carotenoid production indicated that carotenogenesis genes from $M$. aurum had been successfully expressed in $M$. smegmatis. The production of lycopene from IPP needs GGPP synthase, phytoene synthase and phytoene desaturase enzymes [22] with Intermediate precursors of phytoene, phytofluene, $\zeta$-carotene, and neurosporene, successively [6]. However, none of these intermediates was detected in this study, which is perfectly consistent with the findings of Houssaini-Iraqui et al. [22] who reported that carotenes were converted into lycopene.

The production of lycopene using microbial sources is presently of great interest [8, 27]. M. smegmatis containing pC51 plasmid produces a significant quantity of lycopene. This production may be improved by transcribing the pC51 inserted fragment from a strong promoter, and eventually, this system could be used as a source of production of this carotenoid.

It was also found that lycopene is capable to protect M. smegmatis significantly, in vitro and in vivo, against the lethal action of UV radiation. UV radiation acts indirectly on the cellular constituents, through oxidative mechanisms that form reactive oxygen species (ROSs) [28]. The latters have the potential to damage critical cellular components such as: nucleic acids, proteins, lipids, polysaccharides [29]. This leads in most cases to irreversible modifications [30]. As a result, ROSs are emerging as important actors in the etiology of neurodegenerative disorders such as Alzheimer and Parkinson [31], cancer and cardiovascular disease (CVD) [32]. Based on its features and intrinsic properties, lycopene provides opportunities for reducing oxidative damages due to its strong antioxidant activity. The presence of a significant number of conjugated dienes in its structure is responsible of the high antioxidant activity of the lycopene. This allows lycopene to single oxygen activity (the quenching ability of this oxygen is two and ten times higher than that of $\beta$-carotene and $\alpha$-tocopherol, respectively, [10]) and its free radical scavenging capacity [33]. Therefore, lycopene can effectively contribute to prevent a range of oxidative damage, toxicity [34], and some chronic diseases such as cancer [35], CVD [36] and degenerative diseases [37].

According to the UV light survival tests, it appears that lycopene can significantly reduce the lethal action of UV light in both in vivo and in vitro experiments. These results are in perfect agreement with the data published by Houssaini-Iraqui et al. [22] and Srinivasan et al. [34] who reported that lycopene has a protective effect against UV radiation.

Finally, it is well known that many sunscreens contain substances that have some toxicity effect on skin health. Recent research trends to the use of antioxidants in sunscreens to provide photoprotection like plants with antioxidants [38, 39]. The results obtained in this study highlighted the protective effect of lycopene against UV damage. Therefore, it would be important to prepare a commercial sunscreen based on lycopene to maintain a healthy skin of the consumer.

\section{CONCLUSION}

In conclusion, $M$. smegmatis used as a host of a plasmid containing lycopene genes can form orange colonies on sauton plate, and the production found to be important (1.41 mg/g (dry weight) of lycopene). It was found that this carotene has antioxidant activities and protect the bacterial cells from the lethal action of UV irradiation in vivo and in vitro and deserves additional research to improve the production of lycopene by $M$. smegmatis in order to use it as a bioalternative source for large-scale production.

\section{AUTHORS CONTRIBUTIONS}

All authors had contributed equally to the experimental part, writing, and correction of the manuscript.

\section{CONFLICT OF INTERESTS}

We certify that we have no conflict of interest with any financial organization.

\section{REFERENCES}

1. Armstrong GA. Genetics of eubacterial carotenoid biosynthesis: a colorful tale. Annu Rev Microbiol 1997;51:629-59.

2. Sugawara T, Yamashita K, Asai A, Nagao A, Shiraishi T, Imai I, et al. Esterification of xanthophylls by human intestinal caco-2 cells. Arch. Biochem Biophys 2009;483:205-12.

3. Amengual J, Lobo GP, Golczak M, Li HNM, Klimova T, Hoppel CL, et al. A mitochondrial enzyme degrades carotenoids and protects against oxidative stress. FASEB J 2011;25:948-59.

4. Hernandez-Almanza A, Montanez J, Martinez G, AguilarJimenez A, Contreras-Esquivel JC, Aguilar CN. Progress in microbial production. Trends Food Sci Technol 2016;56:142-8.

5. Schnurr G, Schmidt A, Sandmann G. Mapping of a carotenogenic gene cluster from Erwinia herbicola and functional identification of six genes. FEMS Microbiol Lett 1991;78:157-61.

6. Chamovitz D, Misawa N, Sandmann G, Hirschberg J. Molecular cloning and expression in Escherichia coli of a cyanobacterial gene coding for phytoene synthase, a carotenoid biosynthesis enzyme. FEBS Lett 1992;296:305-10. 
7. Krügel $H$, Krubasik $P$, Weber $K$, Saluz HP, Sandmann G. Functional analysis of genes from Streptomyces griseus involved in the synthesis of isorenieratene, a carotenoid with aromatic end groups, revealed a novel type of carotenoid desaturase. Biochim Biophysica Acta 1999;1439:57-64.

8. Araya Garay JM, Feijoo Siota L, Veiga Crespo P, Villa TG. cDNA cloning of a novel gene codifying for the enzyme lycopene $\beta$ cyclase from Ficus carica and its expression in Escherichia coli. Appl Microbiol Biotechnol 2011;92:769-77.

9. Suwanaruang T. Analyzing lycopene content in fruits. Agric Agric Sci Proc 2016;11:46-8.

10. Di Mascio P, Kaiser S, Sies H. Lycopene as the most efficient biological carotenoid singlet oxygen quencher. Arch Biochem Biophys 1989;274:532-8.

11. Sahin K, Yazlak H, Orhan C, Tuzcu M, Akdemir F, Sahin N. The effect of lycopene on antioxidant status in rainbow trout (Oncorhynchus mykiss) reared under high stocking density. Aquaculture 2014;418:132-8.

12. Soares NDCP, Teodoro AJ, Oliveira FL, Santos CADN, Takiya CM, Junior OS, et al. Influence of lycopene on cell viability, cell cycle, and apoptosis of human prostate cancer and benign hyperplastic cells. Nutr Cancer 2013;65:1076-85.

13. Campos KKD, Araujo GR, Martins TL, Bandeira ACB, de Paula Costa G, Talvani A, et al. The antioxidant and anti-inflammatory properties of lycopene in mice lungs exposed to cigarette smoke. J Nutr Biochem 2017;48:9-20.

14. Hazewindus M, Haenen GRMM, Weseler AR, Bast A. The antiinflammatory effect of lycopene complements the antioxidant action of ascorbic acid and $\alpha$-tocopherol. Food Chem 2012;132: 954-8.

15. Sung WS, Lee IS, Lee DG. Damage to the cytoplasmic membrane and cell death caused by lycopene in Candida albicans. J Microbiol Biotechnol 2007;17:1797-804.

16. Das A, Yoon SH, Lee SH, Kim JY, Oh DK, Kim SW. An update on microbial carotenoid production: application of recent metabolic engineering tools. Appl Microbiol Biotechnol 2007; 77:505-12.

17. Nobre BP, Gouveia L, Matos PG, Cristino AF, Palavra AF, Mendes RL. Supercritical extraction of lycopene from tomato industrial wastes with ethane. Molecules 2012;17:8397-407.

18. Lopez Nieto MJ, Costa J, Peiro E, Mendez E, Rodriguez Saiz M, De la Fuente JL, et al. Biotechnological lycopene production by mated fermentation of Blakeslea trispora. Appl Microbiol Biotechnol 2004;66:153-9.

19. Snapper SB, Melton RE, Mustafa S, Kieser T, Jacobs WR. Isolation and characterization of efficient plasmid transformation mutants of Mycobacterium smegmatis. Mol Microbiol 1990;4:1911-9.

20. Hassi M, Haggoud A, El Mzibri M, Ibnsouda S, Houari A, Iraqui $M$. Isolation and identification of a staphylococal strain with an anti-mycobacterial activity and study of its mode of action. Ann Microbiol 2007;57:651-6.

21. Papa F, Riviere M, Fournie JJ, Puzo G, David H. Specificity of a Mycobacterium kansasii phenolic glycolipid (mycoside A) immune serum. J Clin Microbiol 1987;25:2270-3.
22. Houssaini Iraqui $\mathrm{M}$, Khamlichi N, El Yamani J, Rastogi N Response of Escherichia coli Containing mycobacterial carotene genes to UV radiation. J Biomed Biotechnol 2001;1:79-84.

23. Houssaini Iraqui M, Lazraq MH, Clavel Seres S, Rastogi N, David HL. Cloning and expression of Mycobacterium aurum carotenogenesis genes in Mycobacterium smegmatis. FEMS Microbiol Lett 1992;69:239-44.

24. Lu C, Engelmann NJ, Lila MA, Jr JWE. Optimization of lycopene extraction from tomato cell suspension culture by response surface methodology. J Agric Food Chem 2008;56:7710-4.

25. Dagnelie P. Statistiques theoriques et appliquees-tome 1 statistique descriptive et bases de l'inférence statistique; 1998.

26. Ausich RL. Commercial opportunities for carotenoid production by biotechnology. Pure Appl Chem 1997;69:2169-73.

27. Zhu F, Lu L, Fu S, Zhong $\mathrm{X}, \mathrm{Hu} \mathrm{M}$, Deng $\mathrm{Z}$, et al. Targeted engineering and scale-up of lycopene overproduction in Escherichia coli. Process Biochem 2015;50:341-6.

28. Shore RE. Radiation-induced skin cancer in humans. Med Pediatr Oncol 2001;36:549-54.

29. Won EJ, Han J, Lee Y, Kumar KS, Shin KH, Lee SJ, et al. In vivo effects of UV radiation on multiple endpoints and expression profiles of DNA repair and heat shock protein (Hsp) genes in the cycloid copepod Paracyclopina nana. Aquat Toxicol 2015;165:1-8.

30. Butnariu MV, Giuchici CV. The use of some nanoemulsions based on aqueous propolis and lycopene extract in the skin's protective mechanisms against UVA radiation. J Nanobiotechnol 2011;9:3.

31. Bhat AH, Dar KB, Anees S, Zargar MA, Masood A, Sofi MA, et al. Oxidative stress, mitochondrial dysfunction and neurodegenerative diseases; a mechanistic insight. Biomed Pharmacother 2015;74:101-10.

32. Mei Y, Thompson MD, Cohen RA, Tong X. Autophagy and oxidative stress in cardiovascular diseases. Biochim Biophys Acta 2015;1852:243-51.

33. Martinez A, Melendez Martinez AJ. Lycopene, oxidative cleavage derivatives, and antiradical activity. Comput Theor Chem 2016;1077:92-8.

34. Srinivasan M, Kalpana KB, Devipriya N, Menon VP. Protective effect of lycopene on whole body irradiation induced liver damage of swiss albino mice: a pathological evaluation. Biomed Prev Nutr 2014;4:87-94.

35. Lee LK, Foo KY. An appraisal of the therapeutic value of lycopene for the chemoprevention of prostate cancer: a nutrigenomic approach. Food Res Int 2013;54:1217-28.

36. Arab L, Steck S. Lycopene, and cardiovascular disease. Am J Clin Nutr 2000;71:1691S-5S.

37. Prema A, Janakiraman U, Manivasagam T, Thenmozhi AJ Neuroprotective effect of lycopene against MPTP induced experimental Parkinson's disease in mice. Neurosci Lett 2015;599:12-9.

38. Anitha T. Medicinal plants used in skin protection. Asian J Pharm Clin Res 2012;5 Suppl 3:35-8.

39. Priyanka S, Mary SRI, Nandini HS, Kutty AVM, Kiranmayee P. A pilot study on sun protection factor of plant extracts: an observational study. Asian J Pharm Clin Res 2018;11:67-71. 